\title{
Developing the indonesian government enterprise architecture framework appropriate for Indonesian government agencies
}

\author{
Asbartanov Lase, Benny Ranti \\ Bina Nusantara University, Indonesia
}

\begin{tabular}{l}
\hline \hline Article Info \\
\hline Article history: \\
Received Feb 10, 2018 \\
Revised Mar 6, 2019 \\
Accepted Nov 13, 2019 \\
\hline
\end{tabular}

\section{Keywords:}

Australian government architecture

Enterprise architecture Government enterprise architecture

TOGAF

\begin{abstract}
This research was conducted to develop the Indonesian Government Enterprise Architecture (IGEA) framework which is suitable for Indonesian government agencies. Due to their complexity and expensive implementation cost, existing EA frameworks such as TOGAF and Zachman have so far not been the choice for building GEA by some countries including Australia and New Zealand. Those countries have built their own GEA namely Australia's AGA and New Zealand's GEA-NZ, respectively. Learning from this experience, the authors did a research to build Indonesia's GEA or IGEA. This paper explains the research process which starts from mapping or comparing TOGAF, AGA, and GEA-NZ frameworks to get the underlying foundation for building GEA, analyzing framework artifacts, to building IGEA by adding specific Indonesian regulations and policies such as RPJMN and Nawacita. This IGEA framework is expected to become a reference for developing EA not only at institutional level but also the most important thing at national or cross institutional level, in order to increase the effectiveness of government IT spending.
\end{abstract}

Copyright () 2019 Institute of Advanced Engineering and Science. All rights reserved.

\section{Corresponding Author:}

Asbartanov Lase,

Bina Nusantara University,

J1 Kebon Jeruk Raya No.27, Jakarta 11530, Indonesia.

Email: asbartanov.lase@binus.ac.id

\section{INTRODUCTION}

Enterprise Architecture (EA) is an activity of organizing data to achieve the goal of organization's business process and is a blueprint which explains how the IT elements and information management work together as a unity [1]. The framework usually used and implemented is The Open Group Architecture Framework (TOGAF), Zachman, Federal Enterprise Architecture Framework (FEAF), and Gartner [2]. However, these existing EA frameworks are difficult to apply to government agencies and in addition their implementation fees are also very expensive [3]. According to Rouhani et al., TOGAF is a complex EA framework in the process and modelling [4]. Countries such as Australia and New Zealand have made and applied their own version of Government EA (GEA) framework namely Australian Government Architecture (AGA) and Government Enterprise Architecture New Zealand (GEA-NZ), respectively. GEA framework covers elements inside a government such as strategic planning, business process, resource, system, infrastructure, institution architecture, principles and guide between operation [5].

The purpose of this research is to compare and analyze TOGAF, AGA, and GEA-NZ frameworks in particular to get the foundation for developing the Indonesian GEA (IGEA) framework. IGEA is aimed to contribute to the development of the underlying EA framework for all government agencies in Indonesia. By having IGEA it is hoped that Indonesia can follow Australia, New Zealand, Singapore, Vietnam, and other countries, who have implemented their own GEA in order to make IT spending in those countries much more efficient and effective, especially to avoid redundant, disconnected, and unintegrated IT implementations in the government sector. 


\section{RESEARCH METHOD}

This section explains the comparison among TOGAF, AGA and GEA-NZ frameworks both at the Architecture and Artifact Levels to determine factors in establishing the IGEA framework. The research was conducted in 3 stages as explained in the following 3 sub-sections.

\subsection{Stage 1: Comparing TOGAF, AGA and GEA-NZ Frameworks at the Architecture Level}

ANSI/IEEE Std 1471-2000, an architecture is the fundamental organization of a system, embodied in its components, their relationship to each other and the environment, and the principles governing its design and evolution. Enterprise Architecture The comparison result is summarized in Table 1.

Table 1. Comparing TOGAF, AGA, and GEA-NZ frameworks at the architecture level

\begin{tabular}{llll}
\hline \multicolumn{1}{c}{ TOGAF [6] } & \multicolumn{1}{c}{ AGA [7] } & \multicolumn{1}{c}{ GEA-NZ [8] } & Preliminary \\
\hline $\begin{array}{l}\text { Preliminary } \\
\text { Architecture Vision }\end{array}$ & & & Architecture Vision \\
Business Architecture & Performance Reference Model (PRM) & Performance & Business Architecture \\
Data Architecture & Business Reference Model (BRM) & Business & Data Architecture \\
Application Architecture & Data Reference Model (DRM) & Data \& Information & Application Architecture \\
Technology Architecture & Technical Reference Model (TRM) & Application \& ICT Services & Anfrastructure \\
\hline
\end{tabular}

Table 1 shows that at the Architecture Level those compared frameworks similarly focus on the Business, Data, Application, and Technology Architectures although some of them use different naming or a combination of functions. For example, a combination of PRM and BRM in AGA represents Business Architecture, whereas the function of SRM in AGA, which explains the sharing and reuse of applications across horizontal service areas independent of business functions, characterizes Application Architecture. This comparison result is aligned with the research results conducted by Spewak and Ojo which confirm that those four architectures are the foundation of EA $[9,10]$.

According to Spewak a definition of each architecture will be explained briefly. Business Architecture is the compilation of a knowledge base about the business functions and the information used in conducting and supporting the various business process. Data Architecture identifies and defines the major kinds of data that support the business functions defined in the business model. Application Architecture is to define the major kinds of applications needed to manage the data and support the business function of the enterprise. It is a definition of what applications will do to manage data and provide information to people performing business functions. Technology Architecture is to define the major kinds of technologies needed to provide an environment for the applications that are managing data [10].

TOGAF's Preliminary and Architecture Vision are added into this level because their artifacts can be used to show the baseline of the architectures. Preliminary describe the preparation and initiation activities required to meet the business directive for a new enterprise architecture, including the definition of an organization-specific architecture framework and the definition of principles. Architecture Vision describe defining scope, identifying stakeholders, creating architecture vision and obtaining approvals [6].

Based on the above comparison process, the IGEA Framework at the Architecture Level is summarized and depicted in Figure 1.

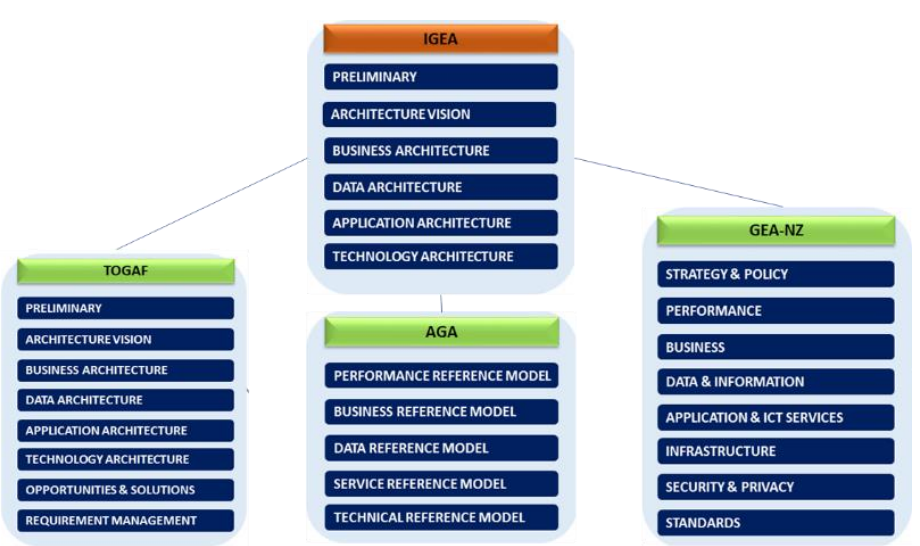

Figure 1. IGEA Framework at the architecture level 


\subsection{Stage 2: comparing TOGAF, AGA, and GEA-NZ frameworks at the artifact level}

Artifact is an architectural work product that describes an aspect of the architecture. Artifacts are generally classified as text (principle or list of things), catalog (list of things), matrices (showing relationships between things), and diagrams (picture or things) [6]. The comparison result is summarized in Table 2.

Preliminary was chosen to define the strategic direction, goals, and initiatives of the enterprise and provides clear descriptions of the contribution that technology information will make in achieving these goals. Strategic begins with a clear statement of the enterprise purpose, complimented by a succinct statement of the vision for success [11].

Architecture Vision was chosen to facilitate shared understanding and agreement among stakeholders on the scope and the outcome of the EA engagement. Architecture Vision also to identifies the business services of the organization and the contribution of technology to support those processes [20].

Table 2. Comparing TOGAF, AGA and GEA-NZ frameworks at the artifact level (Preliminary)

\begin{tabular}{|c|c|c|c|c|}
\hline TOGAF [6] & AGA [7] & GEA-NZ [8] & $\begin{array}{l}\text { Result of Artifacts } \\
\text { Equivalent }\end{array}$ & $\begin{array}{l}\text { Type of } \\
\text { Artifacts }\end{array}$ \\
\hline $\begin{array}{c}\text { Architecture Principle: } \\
\text { Principles are general rules and } \\
\text { guidelines, intended to be enduring and } \\
\text { seldom amended, that inform and } \\
\text { support the way in which an } \\
\text { organization sets about fulfilling its } \\
\text { mission. }\end{array}$ & $\begin{array}{c}\text { AGA does not use } \\
\text { architecture principle } \\
\text { artifact in develop EA } \\
\text { framework. }\end{array}$ & $\begin{array}{l}\text { GEA-NZ does not } \\
\text { use architecture } \\
\text { principle artifact in } \\
\text { develop EA } \\
\text { framework. }\end{array}$ & $\begin{array}{c}\text { Architecture } \\
\text { Principle This artifact } \\
\text { was chosen to define } \\
\text { principle, rules and } \\
\text { guidelines to built } \\
\text { organization. }\end{array}$ & Text \\
\hline $\begin{array}{l}\text { Architecture Goals: } \\
\text { To provide a cross-organizational } \\
\text { reference of how an organization meets } \\
\text { its drivers in practical terms throught } \\
\text { goals, objectivities and measures. }\end{array}$ & $\begin{array}{l}\text { AGA does not use } \\
\text { architecture goals } \\
\text { artifact in develop EA } \\
\text { framework. }\end{array}$ & $\begin{array}{l}\text { GEA-NZ does not } \\
\text { use architecture } \\
\text { goals artifact in } \\
\text { develop EA } \\
\text { framework. }\end{array}$ & $\begin{array}{l}\text { Architecture Goals } \\
\text { This artifact was } \\
\text { chosen to define } \\
\text { purpose, objectives } \\
\text { and target from } \\
\text { organization. }\end{array}$ & Text \\
\hline
\end{tabular}

Table 2. Comparing TOGAF, AGA and GEA-NZ frameworks at the artifact level (Data architecture)

\begin{tabular}{|c|c|c|c|c|}
\hline TOGAF [6] & AGA [7] & GEA-NZ [8] & $\begin{array}{c}\text { Result of Artifacts } \\
\text { Equivalent }\end{array}$ & $\begin{array}{l}\text { Type of } \\
\text { Artifacts }\end{array}$ \\
\hline $\begin{array}{l}\text { Data Entity/Data } \\
\text { Component Catalog: } \\
\text { The purpose of the } \\
\text { Data Entity/Data } \\
\text { Component catalog is } \\
\text { to identify and } \\
\text { maintain a list of all } \\
\text { the data use across the } \\
\text { enterprise, including } \\
\text { data entities and also } \\
\text { the data components } \\
\text { where data entities are } \\
\text { stored. }\end{array}$ & $\begin{array}{c}\text { Data Context: } \\
\text { Facilitates discovery of data } \\
\text { through an approach to the } \\
\text { categorization of data } \\
\text { according to taxonomies. } \\
\text { Additionally, it enables the } \\
\text { definition of authoritative data } \\
\text { assets within a Community of } \\
\text { Interest (COI2). }\end{array}$ & $\begin{array}{l}\text { Data Reference Taxonomy: } \\
\text { The data and information } \\
\text { reference taxonomy define a } \\
\text { standard means by which data } \\
\text { may be described, } \\
\text { categorized, and shared, and } \\
\text { it facilitates discovery and } \\
\text { exchange of core information } \\
\text { across organizational } \\
\text { boundaries. }\end{array}$ & $\begin{array}{c}\text { Data Catalog } \\
\text { This artifact was } \\
\text { chosen to define } \\
\text { data categories used } \\
\text { in designing data } \\
\text { architecture. }\end{array}$ & Catalog \\
\hline $\begin{array}{l}\text { Data Entity/Business } \\
\text { Function Matrix: } \\
\text { The purpose of the } \\
\text { Data Entity/Business } \\
\text { Function matrix is to } \\
\text { depict the relationship } \\
\text { between data entities } \\
\text { and business functions } \\
\text { within the enterprise. }\end{array}$ & $\begin{array}{l}\text { Data Description: } \\
\text { Provides a means to uniformly } \\
\text { describe data, thereby } \\
\text { supporting its discovery and } \\
\text { sharing. }\end{array}$ & $\begin{array}{l}\text { Data Reference Taxonomy: } \\
\text { The data and information } \\
\text { reference taxonomy define a } \\
\text { standard means by which data } \\
\text { may be described, } \\
\text { categorized, and shared, and } \\
\text { it facilitates discovery and } \\
\text { exchange of core information } \\
\text { across organizational } \\
\text { boundaries. }\end{array}$ & $\begin{array}{l}\text { Relation Between } \\
\text { Data Entity } \\
\text { This artifact was } \\
\text { chosen to define } \\
\text { relation between } \\
\text { data entity and } \\
\text { organization } \\
\text { function. }\end{array}$ & Matrix \\
\hline $\begin{array}{l}\text { Logical Data Diagram: } \\
\text { Logical Data Diagram } \\
\text { is to depict logical } \\
\text { views relationships } \\
\text { among the critical data } \\
\text { entities within the } \\
\text { enterprise }\end{array}$ & $\begin{array}{l}\text { Data Context: } \\
\text { Facilitates discovery of data } \\
\text { through an approach to the } \\
\text { categorization of data } \\
\text { according to taxonomies. } \\
\text { Additionally, it enables the } \\
\text { definition of authoritative data } \\
\text { assets within a Community of } \\
\text { Interest (COI2). }\end{array}$ & $\begin{array}{l}\text { Party Domain Model: } \\
\text { The party domain model } \\
\text { (PDM) describes the } \\
\text { management of the core } \\
\text { identity, relationships and } \\
\text { channel preferences of a } \\
\text { Party, where a Party is } \\
\text { defined as an individual or } \\
\text { organization. }\end{array}$ & $\begin{array}{l}\text { Logical Data } \\
\text { Diagram: } \\
\text { This artifact was } \\
\text { chosen to define } \\
\text { model's information } \\
\text { gathered from } \\
\text { business } \\
\text { requirements. }\end{array}$ & Diagram \\
\hline
\end{tabular}


Table 2. Comparing TOGAF, AGA and GEA-NZ frameworks at the artifact level (Business architecture)

\begin{tabular}{|c|c|c|c|c|}
\hline TOGAF [6] & AGA [7] & GEA-NZ [8] & $\begin{array}{c}\text { Result of Artifacts } \\
\text { Equivalent }\end{array}$ & $\begin{array}{l}\text { Type of } \\
\text { Artifacts }\end{array}$ \\
\hline $\begin{array}{l}\text { Business Footprint Diagram: } \\
\text { A Business Footprint } \\
\text { diagram describes the links } \\
\text { between business goals, } \\
\text { organizational units, } \\
\text { business functions, and } \\
\text { services, and maps these } \\
\text { functions to the technical } \\
\text { components delivering the } \\
\text { required capability. }\end{array}$ & $\begin{array}{c}\text { Business Area - Service for } \\
\text { Citizens: } \\
\text { The Services for Citizens } \\
\text { Business Area describes the } \\
\text { mission and purpose of the } \\
\text { Australian Government in } \\
\text { terms of the services it } \\
\text { provides both to and on behalf } \\
\text { of Australian individuals, } \\
\text { businesses and other } \\
\text { organizations. }\end{array}$ & $\begin{array}{l}\text { Business Referense } \\
\text { Taxonomy: Business } \\
\text { reference taxonomy } \\
\text { defines the business } \\
\text { terminology, and provides } \\
\text { a coherent description and } \\
\text { conceptual structure of the } \\
\text { functions and services for } \\
\text { New Zealand. }\end{array}$ & $\begin{array}{l}\text { Vision and Mission } \\
\text { This artifact was } \\
\text { chosen to define } \\
\text { government vision } \\
\text { and mission which } \\
\text { will be used as } \\
\text { foundations to } \\
\text { determine goals to be } \\
\text { reached by IT } \\
\text { solutions. }\end{array}$ & Text \\
\hline \multirow[t]{2}{*}{$\begin{array}{c}\text { Business } \\
\text { Service/Information } \\
\text { Diagram: } \\
\text { The Business } \\
\text { Service/Information } \\
\text { diagram shows the } \\
\text { information needed to } \\
\text { support one or more } \\
\text { business services. The } \\
\text { Business } \\
\text { Service/Information } \\
\text { diagram shows what data is } \\
\text { consumed by or produced } \\
\text { by a business service and } \\
\text { may also show the source of } \\
\text { information }\end{array}$} & $\begin{array}{l}\text { Business Area - Service for } \\
\text { Paths: } \\
\text { Provides the avenues through } \\
\text { which government services for } \\
\text { citizens are provided. The } \\
\text { Service Paths Business Area } \\
\text { represents the functions used by } \\
\text { the Australian Government in } \\
\text { providing its Services for } \\
\text { Citizens }\end{array}$ & $\begin{array}{l}\text { Business Referense } \\
\text { Taxonomy: Business } \\
\text { reference taxonomy } \\
\text { defines the business } \\
\text { terminology, and provides } \\
\text { a coherent description and } \\
\text { conceptual structure of the } \\
\text { functions and services for } \\
\text { New Zealand. }\end{array}$ & $\begin{array}{l}\text { Business Process } \\
\text { This artifact was } \\
\text { chosen to define } \\
\text { business processes } \\
\text { and information } \\
\text { produced and needed } \\
\text { by each business } \\
\text { function within the } \\
\text { organization and to } \\
\text { show which part of } \\
\text { the business } \\
\text { processes can be } \\
\text { automated and } \\
\text { integrated. }\end{array}$ & Diagram \\
\hline & $\begin{array}{l}\text { Business Area - Service for } \\
\text { Paths: } \\
\text { Provides the avenues through } \\
\text { which government services for } \\
\text { citizens are provided. The } \\
\text { Service Paths Business Area } \\
\text { represents the functions used } \\
\text { by the Australian Government } \\
\text { in providing its Services for } \\
\text { Citizens. }\end{array}$ & $\begin{array}{l}\text { New Zealand Public } \\
\text { Sector: } \\
\text { The structure of New } \\
\text { Zealand's Public Sector, } \\
\text { this includes the public } \\
\text { services, state services, } \\
\text { state sector and public } \\
\text { sector and the government } \\
\text { sectors and clusters. }\end{array}$ & $\begin{array}{l}\text { Public Service } \\
\text { This artifact was } \\
\text { chosen to define } \\
\text { public services } \\
\text { including their } \\
\text { standard, provided by } \\
\text { the government } \\
\text { organization. }\end{array}$ & Catalog \\
\hline
\end{tabular}


Table 2. Comparing TOGAF, AGA and GEA-NZ frameworks at the artifact level (Application architecture)

\begin{tabular}{|c|c|c|c|c|}
\hline TOGAF [6] & AGA [7] & GEA-NZ [8] & $\begin{array}{l}\text { Result of Artifacts } \\
\text { Equivalent }\end{array}$ & $\begin{array}{l}\text { Type of } \\
\text { Artifacts }\end{array}$ \\
\hline $\begin{array}{l}\text { Application Portfolio } \\
\text { Diagram: } \\
\text { The purpose of this } \\
\text { catalog is to identify and } \\
\text { maintain a list of all the } \\
\text { applications in the } \\
\text { enterprise. }\end{array}$ & $\begin{array}{l}\text { The SRM has been structured } \\
\text { across service areas that, } \\
\text { independent of the business } \\
\text { functions, can provide a foundation } \\
\text { for the sharing and re-use of } \\
\text { applications, application } \\
\text { capabilities, components and } \\
\text { business services. The SRM is } \\
\text { constructed hierarchically around } \\
\text { Service Domains, Service Types, } \\
\text { and Service Components. }\end{array}$ & $\begin{array}{l}\text { All of Government } \\
\text { (AoG) Business } \\
\text { Application Asset } \\
\text { Catalogue: } \\
\text { Catalogue of the } \\
\text { significant business } \\
\text { applications across } \\
\text { government taken } \\
\text { from the collective } \\
\text { agency business } \\
\text { application catalogues. }\end{array}$ & $\begin{array}{l}\text { Application Portfolio } \\
\text { This artifact was } \\
\text { chosen to define } \\
\text { baseline applications } \\
\text { and target applications } \\
\text { to be designed. }\end{array}$ & Catalog \\
\hline $\begin{array}{l}\text { Application/Organization } \\
\text { Matrix: } \\
\text { The purpose of this } \\
\text { matrix is to depict the } \\
\text { relationship between } \\
\text { applications and } \\
\text { organizational units } \\
\text { within the enterprise. }\end{array}$ & $\begin{array}{l}\text { The SRM has been structured } \\
\text { across service areas that, } \\
\text { independent of the business } \\
\text { functions, can provide a foundation } \\
\text { for the sharing and re-use of } \\
\text { applications, application } \\
\text { capabilities, components and } \\
\text { business services. The SRM is } \\
\text { constructed hierarchically around } \\
\text { Service Domains, Service Types, } \\
\text { and Service Components. }\end{array}$ & $\begin{array}{l}\text { Application \& ICT } \\
\text { Service Reference } \\
\text { Taxonomy: } \\
\text { The application and } \\
\text { ICT service reference } \\
\text { taxonomy provides the } \\
\text { basis for categorizing } \\
\text { applications and their } \\
\text { components. }\end{array}$ & $\begin{array}{l}\text { Application Matrix: } \\
\text { This artifact was } \\
\text { chosen to define } \\
\text { relationship between } \\
\text { applications and } \\
\text { business unit in an } \\
\text { organization. }\end{array}$ & Matrix \\
\hline $\begin{array}{l}\text { Role Application Matrix: } \\
\text { The purpose of the } \\
\text { Role/Application matrix } \\
\text { is to depict the } \\
\text { relationship between } \\
\text { applications and the } \\
\text { business roles that use } \\
\text { them within the } \\
\text { enterprise. }\end{array}$ & $\begin{array}{l}\text { The SRM has been structured } \\
\text { across service areas that, } \\
\text { independent of the business } \\
\text { functions, can provide a foundation } \\
\text { for the sharing and re-use of } \\
\text { applications, application } \\
\text { capabilities, components and } \\
\text { business services. The SRM is } \\
\text { constructed hierarchically around } \\
\text { Service Domains, Service Types, } \\
\text { and Service Components. }\end{array}$ & $\begin{array}{l}\text { Application \& ICT } \\
\text { Service Reference } \\
\text { Taxonomy: } \\
\text { The application and } \\
\text { ICT service reference } \\
\text { taxonomy provide the } \\
\text { basis for categorizing } \\
\text { applications and their } \\
\text { components. }\end{array}$ & $\begin{array}{l}\text { Application Roles. } \\
\text { This artifact was } \\
\text { chosen to define assign } \\
\text { usage of applications } \\
\text { to the specific roles in } \\
\text { the organization, } \\
\text { understand the } \\
\text { application security } \\
\text { requirements of the } \\
\text { business services and } \\
\text { process supporting the } \\
\text { function. }\end{array}$ & Matrix \\
\hline
\end{tabular}

Table 2. Comparing TOGAF, AGA and GEA-NZ frameworks at the artifact level (Technology architecture)

\begin{tabular}{|c|c|c|c|c|}
\hline TOGAF [6] & AGA [7] & GEA-NZ [8] & $\begin{array}{l}\text { Result of Artifacts } \\
\text { Equivalent }\end{array}$ & $\begin{array}{l}\text { Type of } \\
\text { Artifacts }\end{array}$ \\
\hline $\begin{array}{l}\text { Application/Technology } \\
\text { Matrix: } \\
\text { The Application/Technology } \\
\text { matrix documents the } \\
\text { mapping of applications to } \\
\text { technology platform. }\end{array}$ & $\begin{array}{c}\text { Service Category: } \\
\text { Classify lower levels of } \\
\text { technologies and standards with } \\
\text { respect to the business or } \\
\text { technology function they serve. In } \\
\text { turn, each Service Category is } \\
\text { comprised of one or more Service } \\
\text { Standards. }\end{array}$ & $\begin{array}{l}\text { Infrastructure } \\
\text { Reference Taxonomy: } \\
\text { The infrastructure } \\
\text { reference taxonomy } \\
\text { provides a } \\
\text { categorization schema } \\
\text { for IT infrastructure } \\
\text { assets. }\end{array}$ & $\begin{array}{l}\text { Application/Techno } \\
\qquad \text { logy } \\
\text { This artifact was } \\
\text { chosen to define } \\
\text { relation between } \\
\text { technologies and } \\
\text { applications. }\end{array}$ & Matrix \\
\hline $\begin{array}{l}\text { Environment and Locations } \\
\text { Diagram: } \\
\text { The Environments and } \\
\text { Locations diagram depicts } \\
\text { which locations host which } \\
\text { applications, identifies what } \\
\text { technologies and/or } \\
\text { applications are used at } \\
\text { which locations, and finally } \\
\text { identifies the locations from } \\
\text { which business users } \\
\text { typically interact with the } \\
\text { applications. }\end{array}$ & $\begin{array}{c}\text { Technical Area - Service Interface } \\
\text { \& Integration: } \\
\text { The Service Interface and } \\
\text { Integration Service Area defines } \\
\text { the discovery, interaction and } \\
\text { communication technologies } \\
\text { joining disparate systems and } \\
\text { information providers. }\end{array}$ & $\begin{array}{l}\text { GEA-NZ does not use } \\
\text { environment and } \\
\text { locations artifact in } \\
\text { their framework. }\end{array}$ & $\begin{array}{l}\text { Environment and } \\
\text { Locations } \\
\text { This artifact was } \\
\text { chosen to map } \\
\text { which locations host } \\
\text { which applications. }\end{array}$ & Diagram \\
\hline
\end{tabular}


Table 2. Comparing TOGAF, AGA and GEA-NZ frameworks at the artifact level (Architecture vision)

\begin{tabular}{|c|c|c|c|c|}
\hline TOGAF [6] & AGA [7] & GEA-NZ [8] & $\begin{array}{l}\text { Result of Artifacts } \\
\text { Equivalent }\end{array}$ & $\begin{array}{l}\text { Type of } \\
\text { Artifacts }\end{array}$ \\
\hline $\begin{array}{l}\text { Solution Concept Diagram: } \\
\text { Solution Concept diagram } \\
\text { provides a high-level } \\
\text { orientation of the solution that } \\
\text { is envisaged in order to meet } \\
\text { the objectives of the } \\
\text { architecture engagement. }\end{array}$ & $\begin{array}{l}\text { AGA does not use solution } \\
\text { concept diagram artifact in } \\
\text { develop EA framework. }\end{array}$ & $\begin{array}{l}\text { GEA-NZ does not } \\
\text { use solution concept } \\
\text { diagram artifact in } \\
\text { develop EA } \\
\text { framework. }\end{array}$ & $\begin{array}{l}\text { Solution Concept } \\
\text { Diagram } \\
\text { This artifact was chosen } \\
\text { to define the solutions } \\
\text { and targets information } \\
\text { technology to be } \\
\text { achieved. }\end{array}$ & Diagram \\
\hline
\end{tabular}

Table 2 shows that at the Artifact Level there are 17 artifacts that have been analyzed from TOGAF, AGA, and GEA-NZ artifacts, suitable for government organizations which provide IT-based public services, as follows:

a. Artifacts in Preliminary are focused on defining to prepare the enterprise for the architecture work such as organization identification, architecture principles, organization objectives, organization model for EA.

b. Artifacts in Architecture Vision are focused on defining the vision and mission, policy and regulation, solution \& concept diagram and organization structure.

c. Artifacts in Business Architecture are focused on defining business process, and public service.

d. Artifacts in Data Architecture are focused on defining and identifying data types to support each business function within government organization, including relation between data entities.

e. Artifacts in Application Architecture are focused on defining application needs for the data management in supporting the business function. This artifacts describes the applications list, relation between the application list and the business unit or organization in the application architecture artifacts. The artifacts in this application architecture classify the applications based on the functions in the organization, as well as the list from the applications by considering each role.

Artifacts in Technology Architecture are focused on defining technology needs to support the artifacts on the application architecture. Each artifacts describes the technology list, hardware and data communication. The comparison result of these artifacts will be used to create IGEA structured artifacts.

\subsection{Stage 3: Determining factors to build the IGEA framework}

Factors to determine the IGEA framework are as follows [12]:

- Vision, Objectivities, and Strategies

a. Vision: to provide a sense of direction and purpose to the organization, to guide the development of goals, strategies and organization, to energize and inspire people to action

b. Objectivities: for realizing the vision, goals should be clearly defined \& consistent, broad and overall, categorized and measurable

c. Strategies: for achieving the objectivites integrated action plan including detailed scheduled, resource allocation, roles \& responsibility, feedback and adjustment.

- Laws and Regulations,

a. Laws \& regulations related to privacy issues, laws \& regulations which lead citizens participation

b. Laws \& regulations to reflect changes business process and information systems

c. Laws \& regulations related to governmental information technology architecture and establishment of the integrated computing center.

- Organizational Structure is a structure of roles and responsibilities and mechanisms for cooperation governing the behavior of organizations and individuals within a given field.

- Business Process is a series of activity services provided by organization.

- Information Technology (IT) is a factor that is used to describe or define IT Services such as interoperability, standardization, the technology used. IT can also be used optimally, scalable, and directed.

\section{RESULTS AND ANALYSIS}

The IGEA framework is a framework designed to establish EA in the government level especially in Indonesian ministry. IGEA framework can be used in making decision to support IT services development in the ministry to be better, efficient and more effective. The IGEA framework is made based on the result of comparing TOGAF, AGA and GEA-NZ frameworks at the architecture level, comparing TOGAF, AGA and GEA-NZ frameworks at the artifact level and determining factors to build the IGEA framework. 


\subsection{The Fundamental in arranging the IGEA framework artefacs}

Vision and Mission artifacts of IGEA framework, Policy and Regulation, and Organization Structure include into Architecture Vision as these artifacts are the preparatory phase to define scope, principle, rules, purpose, objectives, targets, and to obtain approval from stakeholders. The following is the fundamental in arranging artifacts on IGEA framework as shown in Table 3.

Table 3. Fundamental IGEA framework (Preliminary)

\begin{tabular}{|c|c|c|}
\hline Artifact & Reference & Type of Artifact \\
\hline $\begin{array}{l}\text { Architecture } \\
\text { Principle }\end{array}$ & $\begin{array}{l}\text { This artifact refers to stage two that chosen is to define principle, rules and guidelines to built } \\
\text { organization. Architecture Principle based on rules and guidelines to use and implement all IT } \\
\text { resources and assets an organization. They must reflect a level of consensus between several } \\
\text { corporate components and areas, constituting the basis for the future IT decisions. This artifact } \\
\text { provides values that guide the IT decision making process, serving as a base for the IT } \\
\text { architecture, development policies and standards. }\end{array}$ & Text \\
\hline $\begin{array}{l}\text { Architecture } \\
\text { Goals }\end{array}$ & $\begin{array}{l}\text { This artifact refers to stage two that chosen is to define purpose, objectives, and target from } \\
\text { an organization. Architecture Goals based on goals represent the decomposition of the strategy } \\
\text { and are aspirations that the enterprise/organization wishes to achieve. This artifact refers based } \\
\text { on Vision of Information and Communication Technology (ICT) development is Informative } \\
\text { Indonesia towards prosperous society through the sustainable development of communication } \\
\text { and information that populist and friendly environmentally within the framework of the } \\
\text { Unitary State of the Republic in Indoensia [13]. }\end{array}$ & Text \\
\hline
\end{tabular}

Table 3. Fundamental IGEA framework (Architecture vision)

\begin{tabular}{|c|c|c|}
\hline Artifact & Reference & Type of Artifact \\
\hline $\begin{array}{l}\text { Vision and } \\
\text { Mission }\end{array}$ & $\begin{array}{l}\text { This artifact refers to stage two that chosen is to define government vision and mission which } \\
\text { will be used as foundations to determine goals to be reached by IT solutions. } \\
\text { Vision and mission based on a mission and vision statement that succinctly captures the } \\
\text { purpose and direction of the organization [11]. Vision and Mission refers to the way in which } \\
\text { a service contributes to the achievement of a business vision or strategy [6]. } \\
\text { Vision, Mission and priority program of the president are elaborated by the ministers into the } \\
\text { initial draft of the RPJMN [14]. }\end{array}$ & Text \\
\hline $\begin{array}{l}\text { Policy and } \\
\text { Regulation }\end{array}$ & $\begin{array}{l}\text { This artifact refers to stage two that chosen is to define government policy and regulation which } \\
\text { will be used as foundations in designing government IT solutions. } \\
\text { Policy and Regulation is based on policy and regulation describe how government IT policy } \\
\text { demands EA provide with appropriate information in order to guide IT Planning process, } \\
\text { budget planning, public service, integration, information share and performance review [15]. } \\
\text { This artifact refers to provide the critical policy, programmatic and managerial foundation to } \\
\text { support government operations in the provision of government services to individuals, business } \\
\text { and other organizations [7]. This artifact also is based on the Indonesian government in their } \\
\text { system of presidential republic of a democratic; Indonesia based on Law, Regulations, } \\
\text { Presidential Regulation, Presidential Decision and Ministerial Regulation made based on the } \\
\text { Laws [16]. Followings are the Laws related to the Policy and Regulation artifact: } \\
\text { 1. Law No. } 11 \text { of } 2009 \text { regarding Electronic Information and Transaction [17] } \\
\text { 2. Law No. } 14 \text { of } 2008 \text { regarding Transparency of Public Information [18] } \\
\text { 3. Law No. } 25 \text { of } 2009 \text { regarding Public Services [19] } \\
\text { 4. Presidential Instruction No. } 3 \text { of } 2003 \text { regarding National Policy and Strategy in E- } \\
\text { Government Development [20] } \\
\text { 5. Governmental Regulation of the Republic of Indonesia No. } 82 \text { of } 2012 \text { regarding the } \\
\text { Enforcement of Electronic System and Transaction [21] } \\
\text { 6. Regulation of the Minister of Communication and Information No. } 41 \text { of 2007 regarding } \\
\text { the Management of Information Technology and National Communication [22] } \\
\text { 7. Nawacita }\end{array}$ & Catalog \\
\hline $\begin{array}{l}\text { Solution } \\
\text { Concept } \\
\text { Diagram }\end{array}$ & $\begin{array}{l}\text { This artifact refers to stage two is define the solutions and targets information technology to be } \\
\text { achieved. Solution Concept Diagram based on provides a high-level orientation of the solution } \\
\text { that is envisaged in order to meet the objectives of the architecture engagement. This artifact } \\
\text { may embody key objectives, requirements, and constraints for the engagement, and also } \\
\text { highlight work areas to be investigated in more detail with formal architecture modeling. The } \\
\text { purpose of this diagram is to quickly onboard align stakeholders for a particular change } \\
\text { initiative so that all participants understand what the architecture engagement is seeking to } \\
\text { achieve and how it is expected that a particular solution approach will meet the needs of the } \\
\text { enterprise. Artifact is also based on the realization of the availability and increased quality of } \\
\text { communication and informatics services to support the focus of government development as a } \\
\text { form of state presence to declare sovereignty and equitable development [23]. }\end{array}$ & Diagram \\
\hline $\begin{array}{l}\text { Organization } \\
\text { Structure }\end{array}$ & $\begin{array}{l}\text { This artifact refers to stage two is to define main task and function of each organization unit } \\
\text { which interacts with IT. Organizational structure is a system used to define a hierarchy within } \\
\text { an organization. It identifies each job, its function and where it reports to within the } \\
\text { organization. This artifact also is based on the listing of all participants that interact with IT, } \\
\text { including users and owners of IT Systems [6]. This artifact refers to the execution of Law } \\
\text { Number } 39 \text { of } 2008 \text { article } 1,2,7,8 \text { [23]. }\end{array}$ & Diagram \\
\hline
\end{tabular}


Table 3. Fundamental IGEA framework (Business architecture)

\begin{tabular}{|c|c|c|}
\hline Artifact & Reference & Type of Artifact \\
\hline Business Process & $\begin{array}{l}\text { This artifact refers to stage two is chosen to define business processes and information } \\
\text { produced and needed by each business function within the organization and to show } \\
\text { which part of the business processes can be automated and integrated. } \\
\text { This artifact is based on business process the basis in formulating the activities } \\
\text { undertaken by the organization, transparent governance by the management and handling } \\
\text { of data between agencies to be integrated. Analysis of business process artifact election } \\
\text { is based on point two nawacita that is build transparency of governance government } \\
\text { clean, effective, democratic, and trusted. This artifact is based on the Law of the Republic } \\
\text { of Indonesia No. } 25 \text { of } 2009 \text { regarding Public Service, article } 1 \text { item } 1 \text { and } 9 \text { [19], } \\
\text { Presidential Instruction Number } 3 \text { of } 2003 \text { regarding the E-Government National } \\
\text { Development Policy and Strategy [20]. }\end{array}$ & Diagram \\
\hline Public Service & $\begin{array}{l}\text { This artifact refers to stage two is chosen to define public services including their } \\
\text { standard, provided by the government organization. } \\
\text { The selection of public service artifacts is based on the point nawacita point } 2 \text { which is } \\
\text { to build clean governance, effective, democratic and reliable. Public services are } \\
\text { corruption-free through transparent IT. The creation of a service culture, mental } \\
\text { revolution, bureaucratic reform and governance with integrity, clean, effective and } \\
\text { efficient [23]. } \\
\text { This artifact also refers to based on the Law of the Republic of Indonesia No. } 25 \text { of } 2009 \\
\text { regarding Public Service, article } 1 \text { item } 1 \text { and } 9 \text { [19], Presidential Instruction Number } 3 \\
\text { of } 2003 \text { regarding the E-Government National Development Policy and Strategy [20]. }\end{array}$ & Catalog \\
\hline
\end{tabular}

Table 3. Fundamental IGEA framework (Data architecture)

\begin{tabular}{|c|c|c|c|}
\hline \multicolumn{2}{|c|}{ Artifact } & Reference & Type of Artifact \\
\hline Data Catal & & $\begin{array}{l}\text { This artifact refers to stage two is chosen to define data categories used in designing } \\
\text { data architecture. This artifact refers to EA that provides the tools and procedures for } \\
\text { the management, determination, and utilization of data. } \\
\text { To identify and maintain a list of all the data use across the organization, including } \\
\text { data entities and also the data components where data entities are stored [6]. } \\
\text { This artifact is based on the Law of the Republic of Indonesia Number } 14 \text { of } 2008 \\
\text { regarding the Transparency of Public Information in article 1, } 2 \text { [18]. }\end{array}$ & Catalog \\
\hline $\begin{array}{l}\text { Relation } \\
\text { Between } \\
\text { Entity }\end{array}$ & Data & $\begin{array}{l}\text { This artifact refers to stage two is chosen to define relation between data entity and } \\
\text { organization function. This artifact refers to EA that provides to create a standard } \\
\text { definition and description for each entity in the data architecture and to provide a } \\
\text { graphical illustration of their interrelationships [10]. } \\
\text { To depict the relationship between data entities and business functions within the } \\
\text { enterprise [6]. } \\
\text { This artifact is based on the Law of the Republic of Indonesia Number } 14 \text { of } 2008 \\
\text { regarding the Transparency of Public Information in article } 1,2 \text { [18]. }\end{array}$ & Matrix \\
\hline $\begin{array}{l}\text { Logical } \\
\text { Diagram }\end{array}$ & Data & $\begin{array}{l}\text { This artifact refers to stage two is chosen to define model's information gathered from } \\
\text { business requirements. This artifact refers to depict logical views relationships among } \\
\text { the critical data entities within the enterprise [6]. } \\
\text { This artifact is based on the Law of the Republic of Indonesia Number } 14 \text { of } 2008 \\
\text { regarding the Transparency of Public Information in article 1, 2[18]. }\end{array}$ & Diagram \\
\hline
\end{tabular}

Table 3. Fundamental IGEA framework (Application architecture)

\begin{tabular}{|c|c|c|}
\hline Artifact & Reference & Type of Artifact \\
\hline $\begin{array}{l}\text { Application } \\
\text { Portfolio Catalog }\end{array}$ & $\begin{array}{l}\text { This artifact refers to stage two is chosen to define baseline applications and target } \\
\text { applications to be designed. } \\
\text { To identify and maintain a list of all the applications in the enterprise [6]. } \\
\text { This artifact is based on the Government Regulation Number } 82 \text { of } 2012 \text { regarding } \\
\text { the Enforcement of Electronic System and Transaction article 7[21]. }\end{array}$ & Catalog \\
\hline $\begin{array}{l}\text { Application } \\
\text { Matrix }\end{array}$ & $\begin{array}{l}\text { This artifact refers to stage two is chosen to define relationship between applications } \\
\text { and business unit in an organization. } \\
\text { To depict the relationship between applications and organizational units within the } \\
\text { enterprise [6]. } \\
\text { This artifact is based on the Government Regulation Number } 82 \text { of } 2012 \text { regarding the } \\
\text { Enforcement of Electronic System and Transaction article } 7 \text { [21]. }\end{array}$ & Matrix \\
\hline Application Role & $\begin{array}{l}\text { This artifact refers to stage two is chosen to define assign usage of applications to the } \\
\text { specific roles in the organization, understand the application security requirements of } \\
\text { the business services and process supporting the function. } \\
\text { To depict the relationship between applications and the business roles that use them } \\
\text { within the enterprise [6]. } \\
\text { This artifact is based on the Government Regulation Number } 82 \text { of } 2012 \text { regarding the } \\
\text { Enforcement of Electronic System and Transaction article } 7 \text { [21]. }\end{array}$ & Matrix \\
\hline
\end{tabular}


Table 3. Fundamental IGEA framework (Technology architecture)

\begin{tabular}{|c|c|c|}
\hline Artifact & Reference & Type of Artifact \\
\hline Technology & This artifact refers to stage two is chosen to define list of technologies used. & Catalog \\
\hline Standard Catalog & $\begin{array}{l}\text { The agreed standards for technology across the enterprise covering technologies, and } \\
\text { versions, the technology lifecycles, and the refresh cycles for the technology [6]. This } \\
\text { artifact is based on the Presidential Regulation Number } 54 \text { of } 2015 \text { regarding the } \\
\text { Ministry of Communication and Information article 13b [24]. }\end{array}$ & \\
\hline $\begin{array}{l}\text { Technology } \\
\text { Matrix }\end{array}$ & $\begin{array}{l}\text { This artifact refers to stage two is chosen to define relation between technologies and } \\
\text { applications. }\end{array}$ & Matrix \\
\hline & $\begin{array}{l}\text { The mapping of applications to the technology platform [6]. } \\
\text { This artifact is based on the Presidential Regulation Number } 54 \text { of } 2015 \text { regarding the } \\
\text { Ministry of Communication and Information article } 13 b \text { [24]. }\end{array}$ & \\
\hline $\begin{array}{l}\text { Environment and } \\
\text { Logical Data } \\
\text { Diagram }\end{array}$ & $\begin{array}{l}\text { This artifact refers to stage two is chosen to map which locations host which } \\
\text { applications. Depict which locations host which applications, identifies what } \\
\text { technologies and/or application are used at which locations, identifies the location } \\
\text { from which business users typically interact with the applications [6]. This artifact is } \\
\text { based on the Presidential Regulation Number } 54 \text { of } 2015 \text { regarding the Ministry of } \\
\text { Communication and Information article } 13 \mathrm{~b} \text { [24]. }\end{array}$ & Diagram \\
\hline
\end{tabular}

IGEA framework on Figure 2 consists of four architectures and seventeen artifacts. IGEA framework is an EA framework which comply with TOGAF framework that makes IGEA framework a minimalist TOGAF framework. IGEA frameworks mainly adopts TOGAF's artifacts because it emphisizes more on EA process detail. In this research, TOGAF, AGA, and GEA-NZ comparison are used in order to eliminate the artifacts from TOGAF's, in which rather complex, so it becomes more minimalistic and suitable to Indonesian govermenment necessities (IGEA framework).

The term of the artifacts used in IGEA framework are derived from TOGAF framework artifacts since they are basic, standard, and more commonly in use in Enterprise Architecture framework

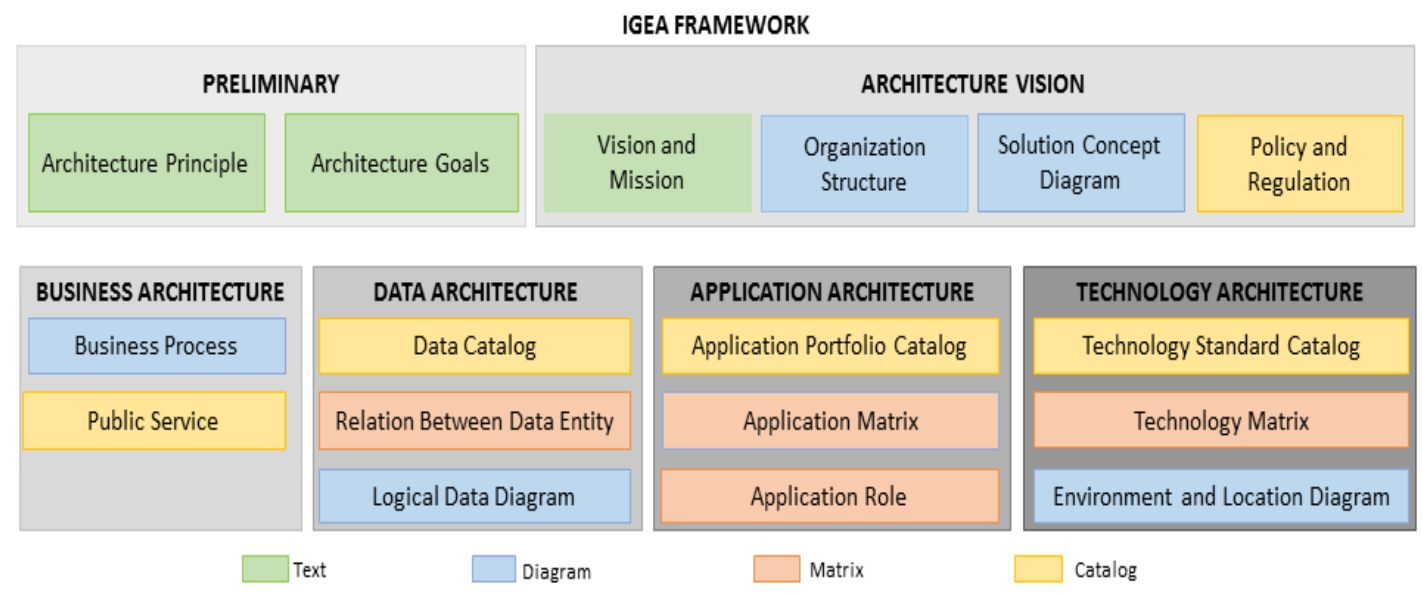

Figure 2. IGEA Framework

\subsection{Proposed IGEA framework implementation}

The proposed implementation of the IGEA framework consists of architecture Principle artifacts, Archticture Goals, Vision \& Mission, Policy \& Regulation, Business Process and Public Service. The Architecture Principle is used to enhance synergy and togetherness in order to enhance the roles in each ministry, integrated data between ministries. Architecture Goals provide equality of understanding and integration of the steps of all elements of government institutions in the framework of implementation of policies, especially in the development of information systems applications, a reference in government institutions by showing the integration relationship between one application with another, both as a function of inter-ministerial relations and service functions to community. Vision and Mission focuses on the vision and mission of the current government. Policy and regulation is regulated in the applicable such as Law No.11 Year 2009 on Information and Electronic Transactions, Law No.14 of 2009 on Public Information Disclosure and Law No.25 of 2009 on Public Service. The Business Process focuses on the activities or business processes that exist in the ministry. Public service focuses on the activities of public services so that the framework of IGEA produces a synergy framework, integrated and can be developed together. 


\section{CONCLUSIONS}

The research aims to developed IGEA framework appropriate for the government agencies in Indonesia. The research led to conclusions as follows:

a) IGEA Framework is done with these three steps: architecture mapping, artifacts equivalence, and referring to factors associated with constitution, RPJMN, and Nawacita. The first step is to map the architecture of TOGAF, AGA, and GEA-NZ in order to get the IGEA framework's architectures. The second step is to equivalence the artifacts from the all architecture level. The artifact equivalence is to find the tantamount description of each artifacts from the architectures. The third step is to build the IGEA framework based on both preceding steps and in accordance with constitution, RPJMN, and Nawacita.b) The three-step IGEA framework development makes IGEA consists of four architectures and seventeen artifacts. The IGEA framework brings common understanding in steps of applying EA for every institutional element in the ministry, so it can be a reference to EA development in the ministry. IGEA can also support the decisionmaking process for IT service development plan to be better, more effective and more efficient. c) Enterprise Architecture framework that widely used and implemented are TOGAF, Zachman, FEAF, and Gartner framework. The existed frameworks, however, are rather hard to implement in government agencies. Not only its complexity, its price for the implementation is rather expensive. Therefore, this complex and high-price TOGAF framework artifacts are eliminated to be such minimalistic and more suitable to Indonesian government agencies needs. The term of the artifacts used in IGEA framework are derived from TOGAF framework artifacts since they are basic, standard, and more commonly in use in Enterprise Architecture framework. d)In IGEA framework, there is Policy \& Regulation artifact and Public Service artifact. Policy \& Regulation artifact defines government policies and regulations which will be used as a foundation for designing IT solution in govenrment, while Public Service artifact defines public services including the standards which will be used by the government. e) This research result shows that IGEA framework needs to be tested in Indonesian government agencies.

\section{REFERENCES}

[1] Cook, M. Building Enterprise Information Architectures:Reengineering Information Systems. Hewlett-Packard Professional. 1996.

[2] Sessions, R. A Comparison of the Top Four Enterprise Architecture Methodologies. Houston: ObjectWatch Inc. 2007.

[3] Nguyen, A. Government Architecture Framework of ITI (ITI-GAF). Jakarta. 2016.

[4] Rouhani, B. D., Mahrin, M. N., Nikpay, F., \& Nikfard, P. Comparison Enterprise Architecture Implementation Methodologies. IEEE Informatics and Creative Multimedia. 2013.

[5] Paul, A., \& Paul, V. A Framework for e-Government Interoperability in Indian Perspective. International Journal of Computer Information Systems and Industrial Management Applications, 582-591. 2014.

[6] TOGAF. TOGAF. The Open Group. 2011.

[7] Steward, A. Australian Government Architecture Reference Models. Australian: AGIMO. 2011.

[8] Deleu, R., Clendon, J., Collier, J., \& Cutforth, P. Government Enterprise Architecture - GEA-NZ 3.0 Context Document. New Zealand: Department of Internal Affairs. 2014.

[9] Ojo, A., Janowski, T., \& Estevez, E. Improving Government Enterprise Architecture Practice Maturity Factor Analysis. IEEE System Science. 2012.

[10] Spewak, S. H., \& Hill, S. C. Enterprise Architecture Planning. United States of America: A Wiley - QED. 1992.

[11] Bernard, S. A. An Introduction to Enterprise Archtiecture. USA: AuthorHouse. 2005.

[12] Yu, S. Best Practices of Korean e-Government. Korea: e-GSC. 2007.

[13] Data center of Ministry of Communication and Information. Jakarta: Menkominfo. 2010.

[14] Presidential Regulation of The Republic of Indonesia number 7 of 2015 on National Ministry Organization. Jakarta: Sekertariat Kabinet RI. 2015.

[15] Lee, Y., J., Kwon, Y., Shin, S., Kim, E. Advancing Government-wide Enterprise Architecture- A Meta-model Approach.. ICACT, 886-892. 2013.

[16] Nuh, M. General Guidance of Organization Technology Information and National Communication. Jakarta: Menkominfo. 2007.

[17] Indonesia Laws Constitutions number 11 of 2008 on Information and Electronic Transection. Jakarta. 2008.

[18] Indonesia Laws Constitutions number 14 of 2008 on public information disclosure. Jakarta Republik Indonesia. 2008.

[19] Indonesia Laws Constitutions number 25 of 2008 on Public Service. Jakarta: Republik Indonesia. 2009.

[20] Indonesia Presidential Instruction number 3 of 2003 on National Policy and Strategy for E-Government Development. Jakarta: Presiden Republik Indonesia. 2003.

[21] Indonesia Government Regulation number 82 of 2012 on Operating system and Electronic Transaction. Jakarta: Republik Indonesia. 2012.

[22] Ministerial of communication and Information Regulation number 41/PERMEN.KOMINFO/11/2007 on General Guidance of Organization Technology Information and National Communication. Jakarta: Menkominfo. 2007.

[23] Strategic Plan of Ministry of Communication and Information. Jakarta: Menkominfo. 2015.

[24] Presidential regulation of the republic of Indonesia number 54 of 2015 on Ministry of Communication and Information. Jakarta: Republik Indonesia. 2015. 